\title{
Manajemen Produksi Program Siaran Ikom Radio 107.7 FM selama Pandemi
}

\section{Covid-19}

\author{
Rizqi Aulia Sakina \\ Program Studi Ilmu Komunikasi, Universitas Muhammadiyah Yogyakarta, Indonesia \\ rizqi.aulia.isip19@mail.umy.ac.id \\ Alifia Ulya'hati Aqilaningrum \\ Program Studi Ilmu Komunikasi, Universitas Muhammadiyah Yogyakarta, Indonesia \\ alifia.u.isip19@mail.umy.ac.id \\ Stephen Aprilyanto \\ Program Studi Ilmu Komunikasi, Universitas Muhammadiyah Yogyakarta, Indonesia \\ stephen.a.isip19@mail.umy.ac.id \\ Diserahkan: 14 Juni 2021; Direvisi: 19 Juni 2021; Diterima: 23 Juni 2021
}

\begin{abstract}
Ikom Radio 107.7 FM is a student community radio located within the University of Muhammadiyah Yogyakarta (UMY). The purpose of establishing this radio is to support academic activities on campus and as a learning medium in the field of radio broadcasting. In the midst of the Covid-19 Pandemic, Ikom Radio 107.7 FM is required to continue to run the broadcast program that has been designed. This study examines the management process and implementation of the IKOM Radio 107.7 FM broadcast program during the pandemic. The purpose of this study was to determine the production management of the IKOM Radio 107.7 FM broadcast program during the Covid-19 pandemic, especially in terms of program determination and procedures for implementing broadcast programs. The research method used in this study is the case study method, by considering several things, such as the focus of the research is to answer "how" and "why" and so on. The object of the research is the production management of the IKOM Radio 107.7 FM broadcast program during the Covid 19 pandemic. The data collection technique was carried out by in-depth interviews and post-production observations with IKOM Radio 107.7 FM. The research subjects were the Director, Program Division and the Technical Division of IKOM Radio 107.7 FM. Based on the results of this study indicate that Ikom Radio 107.7 FM is able to adapt to current conditions by running broadcast programs by streaming through the application.
\end{abstract}

Keywords: Ikom Radio 107.7 FM, Program Production Management, Radio Program

\section{Abstrak}

Ikom Radio 107.7 FM merupakan radio komunitas mahasiswa yang berada dalam lingkungan Universitas Muhammadiyah Yogyakarta (UMY). Tujuan didirikannya radio ini adalah untuk menunjang kegiatan akademik di kampus serta sebagai media pembelajaran di bidang penyiaran radio. Di tengah Pandemi Covid-19, Ikom Radio 107.7 FM dituntut untuk terus menjalankan program siaran yang telah dirancang. Penelitian ini mengkaji mengenai proses manajemen serta pelaksanaan program siaran Ikom Radio 107.7 FM selama masa pandemi. Tujuan penelitian ini adalah untuk mengetahui manajemen produksi program siaran Ikom Radio 107.7 FM selama Pandemi Covid-19, terutama dalam hal penentuan program serta tata cara pelaksanaan program siaran. Metode penelitian yang digunakan dalam penelitian ini adalah metode studi kasus, yaitu dengan mempertimbangkan beberapa hal, seperti fokus penelitian adalah untuk menjawab "bagaimana" dan "mengapa" dan lain sebagainya. Adapun yang menjadi objek penelitiannya adalah manajemen produksi program siaran Ikom Radio 107.7 FM di masa pandemi Covid 19. Teknik pengumpulan data dilakukan dengan wawancara mendalam serta observasi saat pasca produksi dengan pihak Ikom Radio 107.7 FM. Subjek penelitian adalah Direktur, Divisi Program serta Divisi Teknis Ikom Radio 107.7 FM. Berdasarkan hasil dari penelitian ini menunjukkan bahwa Ikom Radio 107.7 FM mampu beradaptasi terhadap keadaan saat ini dengan menjalankan program siaran secara streaming melalui aplikasi.

Kata Kunci: Ikom Radio 107.7 FM, Manajemen Produksi Program, Program Radio 


\section{PENDAHULUAN}

Adanya Pandemi Covid-19 telah membuat banyak hal berubah. Covid-19 merupakan infeksi virus baru yang membuat 90.308 orang terinfeksi per 2 Maret 2020. Sehingga, untuk mencegah penyebaran lebih lanjut pemerintah memutuskan untuk melakukan pembatasan dalam bersosialisasi. Hal ini berimbas pada kegiatan-kegiatan kampus yang berubah sistem menjadi online. Termasuk kegiatan-kegiatan yang akan dilakukan oleh mahasiswa dalam menyalurkan minat bakatnya, salah satunya dalam hal penyiaran.

Penyiaran atau broadcasting adalah keseluruhan proses penyampaian siaran yang dimulai dari penyiapan materi produksi, produksi, penyiapan bahan siaran, kemudian pemancaran sampai kepada penerimaan siaran tersebut oleh pendengar/pemirsa di suatu tempat (Wahyudi dalam Djamal Hidajanto, 2011:3). Pada pasal 1 butir 2, Ketentuan Umum Undang-Undang No. 32/2002 tentang Penyiaran, memberikan definisi khusus mengenai penyiaran sebagai kegiatan pemancarluasan siaran melalui sarana pemancaran dan/atau media lainnya untuk dapat diterima secara serentak dan bersamaan oleh masyarakat dengan perangkat penerima siaran. Salah satu media yang digunakan sebagai pemancarluasan siaran merupakan radio.

Radio merupakan media penyiaran yang hanya bisa didengar, namun bisa didengar dimana saja. Karena hanya berupa suara, radio dapat menciptakan imajinasi bagi pendengarnya, dimana pendengar bebas mengekspresikan apa yang didengar dari radio di pikirannya. Radio memiliki beberapa macam jenis, yaitu radio publik, radio swasta, radio komunitas dan radio berlangganan. Radio yang biasanya ada dalam setiap kampus, masuk ke dalam jenis radio komunitas, termasuk Ikom Radio 107.7 FM.

Menurut Colin Fraser dalam Buku Panduan Radio Komunitas, radio komunitas adalah lembaga layanan nirlaba yang dimiliki dan dikelola oleh komunitas tertentu, umumnya melalui yayasan atau asosiasi. Tujuannya adalah untuk melayani dan memberikan manfaat kepada komunitas dimana lembaga penyiaran tersebut berada (Betty Gama, 2018). Ikom Radio 107.7 FM merupakan radio komunitas mahasiswa yang berada dalam lingkungan Universitas Muhammadiyah Yogyakarta (UMY). Radio ini didirikan oleh Mahasiswa Ilmu Komunikasi UMY pada tahun 1994. Tujuan didirikannya radio ini untuk menunjang kegiatan akademik di kampus serta sebagai media pembelajaran di bidang penyiaran radio.

Ikom Radio 107.7 FM memiliki beberapa program harian andalan, seperti Live in Jogja yang membahas mengenai info seputar Jogja, lalu ada Kzone yang membahas mengenai segala sesuatu yang berhubungan dengan Korea Selatan, ada juga program One Our With yang mendatangkan bintang tamu sehingga bisa berbincang hangat dengan bintang tamu, selanjutnya ada juga program Popcorn yang mengulik film-film dan series, lalu ada Muslim Zone dan Groovie. Baru-baru ini, Ikom Radio 107.7 FM memiliki program siaran baru yang disebut Jam Malam, dalam Jam Malam ada program lainnya seperti sambat, fakta, mitos dan bucin. Terbatasnya akses ke kampus karena pandemi, membuat Ikom Radio 107.7 FM memutar otak agar tujuan dan fungsi Ikom Radio 107.7 FM dapat terlaksana sebagaimana mestinya. Salah satunya dalam memutuskan bagaimana siaran dapat dilakukan meski ada jarak yang terbentang. Terlebih lagi, hal ini merupakan hal baru yang sebelumnya sama sekali belum pernah terjadi.

Berangkat dari latar belakang di atas, rumusan masalah penelitian ini adalah Pandemi Covid-19 membuat Ikom Radio 107.7 FM harus beradaptasi dengan keadaan, yang mengakibatkan proses produksi program siaran menjadi berbeda dari sebelumnya. Lalu, bagaimana manajemen produksi program siaran Ikom Radio 107.7 FM selama masa pandemi ini? Tujuan penelitiannya adalah untuk mengetahui manajemen produksi program siaran Ikom Radio 107.7 FM selama Pandemi Covid-19. Penelitian terdahulu mengenai manajemen produksi program radio dilakukan oleh Puti Andam Sari, Yulinda Sari dan Dyo Rizky. Mereka mengkaji mengenai implementasi manajemen penyiaran Radio Geronimo FM Jogja dalam mempertahankan audiens. Dalam penelitiannya, mereka mengatakan bahwa keberhasilan sebuah program terdapat pada menajemen penyiaran yang baik (Sari et al., 2011). 
Penelitian lain dilakukan oleh Nurhasanah Nasution, ia meneliti mengenai strategi manajemen penyiaran radio swasta Kiss FM dalam menghadapi persaingan informasi digital. Radio Kiss FM sudah bukan lagi radio konvensional yang hanya menyampaikan informasi. Tapi sudah merambah ke media sosial seperti Youtube. Manajemen Radio Kiss FM sudah all in one dalam melakukan siaran melalui on air, off air dan siaran online atau live streaming. Pihak radio juga melakukan aktifitas bersama komunitaskomunitas di luar kegiatan on air. Nurhasanah Nasution mengatakan bahwa mematuhi standar operasional prosedur (SOP) menjadi sangat penting agar tidak terjadi kesalahan informasi bagi stasiun radio pada saat on air dan harus selalu dipatuhi (Nasution, 2018).

Berbeda dengan penelitian terdahulu, penelitian yang kami lakukan berfokus pada manajemen produksi program siaran. Dalam hal ini, kami mencoba mengkaji mengenai manajemen produksi program siaran radio komunitas, yang dalam hal ini Ikom Radio 107.7 FM bertahan selama masa Pandemi Covid-19. Tantangan yang dihadapi Ikom Radio 107.7 FM selama masa Pandemi Covid-19 tentunya lebih berat daripada tantangan yang sudah ada sebelumnya. Penelitian ini penting untuk dilakukan, karena dengan adanya hasil penelitian ini diharapkan mampu menjadi referensi bagi radio komunitas lainnya untuk menjaga eksistensinya dan bertahan selama masa Pandemi Covid-19.

\section{KAJIAN PUSTAKA}

Pandemi Covid-19 membuat banyak tatanan sosial masyarakat berubah. Penyesuaian demi penyesuaian dilakukan agar dapat bertahan di tengah pandemi. Tuntutan perubahan membuat hal-hal yang tidak pernah dibayangkan mulai bermunculan. Kondisi Covid-19 menyadarkan pemerintah, swasta dan masyarakat serta individu untuk menerobos dan mengatasi berbagai kendala dan tantangan dengan yang baru. Cara baru itu juga sebagai salah satu bentuk adaptasi baru, dimana didukung oleh fakta lain yaitu berkembang pesatnya penggunaan Teknologi Informasi berbasis internet yang massif. Kondisi tersebut menjadikan masyarakat menjadi masyarakat online dan mengarah ke digitalisasi. Dengan situasi tersebut, yaitu masyarakat online dan digitalisasi, individu hidup dapat beraktivitas dari mana saja. Sentuhan jari di personal computer dan handphone yang didukung dengan Teknologi Informasi Berbasis Internet dapat mengatasi berbagai kendala yang sebelumnya tidak terpikirkan. Individu dan masyarakat memasuki babak baru masyarakat online dan digitalisasi melingkupi semua sektor kehidupan paling dasar (Husna et al., 2020).

Pandemi Covid-19 menyadarkan masyarakat mengenai penggunaan media sosial dan digitalisasi untuk beraktivitas, berdoa dan bekerja dari rumah. Sejak pandemi Covid-19, kebanyakan individu beraktivitas dari rumah. Aktivitas dari rumah itulah yang menjadikan kesadaran baru untuk mengoptimalkan kegunaan media sosial dan digitalisasi untuk disatukan dengan aktivitas manusia. Individu dan masyarakat menjadi memiliki kesadaran lebih baik dalam penggunaan media sosial dan digitalisasi untuk mendukung bagi upaya lebih produktif dan menguntungkan dari rumah. Media sosial dan digitalisasi menemukan arti dan makna yang lebih luas dan dalam untuk mendukung bagi aktivitas produktif dari rumah. Kesadaran seperti ini semakin baik bila dibanding dengan masa sebelum pandemik Covid-19 (Husna et al., 2020).

Radio merupakan media tanpa visual yang menggunakan dua teknologi yaitu analog dan digital. Frequency Modulation (FM), Amplitude Modulation (AM) dan Short Wave (SW) adalah standar yang digunakan oleh radio analog untuk membawa konten radio. Sedangkan standar teknologi digital terdiri dari Digital Audio Broadcasting (DAB / DAB +), Digital Radio Mondale (DRM) dan High Definition (HD). Penggunaan radio di dunia, khususnya di negara berkembang masih signifikan dan relevan. Statistik menunjukkan bahwa 94\% warga Malaysia mendengarkan radio, Singapura 92\%, dan Filipina 98\% (Nielsen, 2015). Meski begitu, tidak memungkiri juga terjadi penurunan penggunaan radio di Indonesia 
sebesar 44\% dan Jepang 40\%. Namun hal ini masih bisa diimbangi dengan penggunaan radio online dan radio digital (Bharata et al., 2018).

Perubahan teknologi studio di radio digital melibatkan peralihan dari mixer analog yang digunakan menjadi digital mixer yang memudahkan penyiar radio dalam bertugas. Studio Ergonomis didasarkan pada komputer. Kemudian dari segi produksi menghemat waktu produser program untuk mengedit dan mencampurkan suara, efek suara dan suara dalam memproduksi program radio. Dengan kata lain, produksi program radio seperti radio drama, dokumentasi, majalah, iklan niaga dan iklan layanan masyarakat diterbitkan dengan menggunakan komputer tanpa menggunakan pita audio seperti DAT (Bharata et al., 2018).

Radio sebagai perusahaan penyiaran merupakan organisasi yang diatur sedemikian rupa dengan sistem manajemen. Perusahaan penyiaran ini berkaitan erat dengan media massa sehingga manajemen yang digunakan disebut juga dengan manajemen media massa, disingkat menjadi manajemen media. Dalam sebuah perusahaan media terdapat dua kegiatan pokok, yaitu bidang redaksi dan bidang perusahaan. Bidang redaksi bertugas untuk mengelola isi media di luar iklan, sedangkan bidang perusahaan berkaitan dengan pengiklanan dan pemasaran dan bertugas melakukan pengaturan usaha supaya bidang redaksi dapat melaksanakan tugasnya dengan baik (Sugiana et al., 2019).

Saat ini setiap stasiun radio harus bersaing dalam memperebutkan perhatian pendengar. Radio tidak bisa lagi 'memerintahkan' audiens. Radio harus mampu merayu audiens. Hal ini merupakan tantangan terbesar dari semuanya. Kondisi saat ini, tidak memungkinkan untuk sekedar menyiarkan berita, seorang jurnalis radio harus memastikan bahwa berita didengarkan dan dipahami. Untuk menginformasikan, seorang penyiar harus tertarik mengenai berita yang disampaikan (Chantler \& Stewart, 2009).

Pengelolaan secara bisnis pada perusahaan media dilakukan dengan pengelolaan media, isi, dan sumber daya manusia (SDM). Pengelolaan media berhubungan dengan penyajian isi. Hal ini dilakukan untuk memenuhi target market. Pengelolaan isi berkaitan dengan kolom berita atau iklan. Pengelolaan SDM berhubungan dengan pengelolaan peran pekerja radio siaran diantaranya: penyiar, produser, programer. Mereka harus bekerja secara optimal sehingga menghasilkan program siaran yang mampu menarik banyak pendengar. Departemen program dan departemen pemasaran merupakan departemen yang bertanggungjawab dalam hal merencanakan dan memilih program. Dua departmen ini bekerjasama dalam menyusun program yang baik dan memasarkan programnya, sehingga iklan bisa didapatkan oleh pengelola radio dengan demikian penghasilan finansial dapat diperoleh. Departemen pemasaran dapat memberikan masukan atas prospek peringkat acara (rating) bahkan lebih dari itu bisa mempengaruhi pada nilai saham perusahaan media tersebut apabila perusahaan media tersebut telah go public. Hubungan antara kedua bagian ini sangat vital untuk menjaga kesehatan keuangan media penyiaran (Morissan 2008:337 dalam Sugiana et al., 2019).

Morissan dalam Sugiana mengatakan bahwa faktor penting dalam mendukung kesehatan keuangan perusahaan media adalah program acara yang mendapat apresiasi audience, program yang mampu menyedot perhatian khalayaknya sehingga mampu mendatangkan para pengiklan untuk mengiklankan produknya di program acara stasiun tersebut. Oleh karena itu program acara bisa dianalogikan dengan produk atau layanan yang dijual kepada konsumen. Karena itu, program adalah produk yang dibutuhkan orang sehingga bersedia mengikutinya. Dalam hal ini terdapat suatu rumusan dalam dunia penyiaran yaitu program yang baik akan mendapatkan pendengar atau penonton yang lebih besar, sedangkan acara yang buruk tidak akan mendapatkan pendengar atau penonton.

Dalam membuat konten berita, tidak ada kesepakatan pasti yang membuat konten berita terbaik, namun ada satu yang menjadi pertimbangan, yaitu apa yang baru dan berbeda. Wartawan Amerika Charles Dana, yang meninggal pada tahun 1897, mengatakan: "Ketika seekor anjing menggigit seorang pria, itu bukanlah berita, tetapi kapan seorang pria menggigit anjing, itu adalah berita." Aturan umum 
dalam membuat konten adalah menggunakan cerita yang dapat memengaruhi orang dan singkirkan yang tidak mampu memengaruhi (Chantler \& Stewart, 2009).

Beberapa stasiun radio Amerika, menggunakan salah satu dari enam konten kategori dalam memilih cerita, diantaranya adalah:

1. Hati, cerita yang dapat mempengaruhi orang secara emosional, seperti kehilangan atau keberanian dan penyembuhan, tragedi dan perayaan.

2. Dana yang menceritakan hal-hal yang mempengaruhi uang, pengeluaran dan tabungan, termasuk tingkat bunga dan harga properti.

3. Kesehatan, yang bukan hanya menceritakan mengenai apa yang terjadi di rumah sakit lokal tetapi membahas masalah yang lebih luas seperti diet, kebugaran, latihan dan perkembangan medis.

4. Relaksasi, cara orang menghadapi stres, keluarga, waktu luang, liburan dan gaya hidup.

5. Keselamatan yang membahas mengenai kejahatan dan terorisme serta bagaimana menjaga keamanan anak-anak.

6. Lokal yang membahas mengenai apa yang mempengaruhi lingkungan sekitar, nasional dan global (Chantler \& Stewart, 2009).

Untuk membuat program acara dapat disukai dan diapresiasi oleh khalayak, ada empat hal yang harus diperhatikan:

1. Materi acara memiliki kualitas baik dan potensi untuk digemari audience tinggi.

2. Besaran biaya atau ongkos produk program akan menentukan besaran tarif per spot iklan yang harus dibayar para pemasang iklan.

3. Penetapan waktu siaran yang tepat akan berkorelasi dengan penetapan segmentasi, positioning, dan targetting sehingga menentukan keberhasilan program dan pengiklannya juga.

4. Memperkenalkan serta menjual program acara agar dapat mendatangkan pengiklan (Sugiana et al., 2019)

\section{METODE PENELITIAN}

Metode penelitian yang dipilih dalam penelitian ini adalah metode studi kasus. Pemilihan metode studi kasus dalam penelitian ini, dilatarbelakangi bahwa penelitian ini memiliki tujuan untuk menguji pertanyaan dan masalah penelitian. Pengujian terhadap pertanyaan dan masalah penelitian yang tidak dapat dipisahkan antara fenomena serta konteks di mana fenomena tersebut terjadi.

Pemilihan metode penelitian studi kasus dalam penelitian ini dilakukan dengan mempertimbangkan beberapa hal. Pertama, fokus penelitian adalah untuk menjawab pertanyaan "bagaimana" dan "mengapa". Kedua, dalam penelitian studi kasus, peneliti tidak boleh melakukan manipulasi terhadap perilaku obyek yang diteliti yang terlibat di dalam penelitian. Ketiga, peneliti ingin menutupi kondisi kontekstual dilatarbelakangi karena peneliti mempunyai keyakinan bahwa hal itu relevan dengan yang diteliti. Terakhir, adanya batas tidak jelas antara fenomena dan konteks yang diteliti (Yin, 2008). Dalam pelaksanaan penelitian ini, studi kasus dilaksanakan dengan meneliti proses manajemen produksi program siaran Ikom Radio 107.7 FM selama pandemi.

Metode pengumpulan data dalam pelaksanaan penelitian studi kasus dalam penelitian ini dilakukan dengan berbagai cara. Pertama, adalah pengumpulan data dilakukan dengan observasi partisipan. Kekuatan pengumpulan data dengan observasi partisipan berakar pada observasi proses aktual "di lapangan". Peneliti dapat mengamati rutinitas kerja yang sebenarnya, selama observasi, merekam proses pengambilan keputusan, konflik, negosiasi, dan kompromi, yang kesemuanya merupakan bagian dari proses produksi di berbagai tingkatan (Given, 2008). Sayangnya metode pengumpulan data ini menjadi lebih sulit dilakukan di masa pandemi Covid-19, karena adanya keterbatasan ruang gerak. Jika memungkinkan, metode ini dilakukan dengan melakukan observasi pada siaran Ikom Radio 107.7 FM. 
Kedua, pengumpulan data dilakukan dengan wawancara mendalam. Kekuatan utama wawancara sebagai metode adalah kemampuannya untuk menjangkau berbagai perspektif tentang topik tertentu. Berbagai wawancara dapat digunakan untuk menambah informasi dan memperluas sudut pandang dalam penelitian tentang manajemen produksi yang sedang dilakukan ini. Semua wawancara dapat digunakan sebagai perangkat heuristik, karena informasi baru mengarah pada perspektif dan pertanyaan baru untuk subjek selanjutnya (Given, 2008) Dalam penelitian ini, wawancara akan dilakukan kepada Ridho, yang menjabat sebagai direktur di Ikom Radio, Tasya yang menjabat sebagai ketua divisi program di Ikom Radio.

Ketiga adalah dengan studi dokumen dan arsip. Dokumen, bisa berupa surat, memorandum, agenda, dokumen administrasi, artikel surat kabar, atau dokumen apapun yang berkaitan dengan penyelidikan. Triangulasi bukti dengan dokumen berfungsi untuk menguatkan bukti dari sumber lainnya. Dokumen juga dapat dipakai guna menarik kesimpulan pada suatu peristiwa, mengarah pada petunjuk palsu jika peneliti tidak berpengalaman. Dokumen dapat berbentuk arsip, seperti catatan layanan, catatan organisasi, daftar nama, hasil survey (Yin, 2008). Pada penelitian ini, arsip yang diteliti adalah dokumen yang bersumbar dan atau berkaitan dengan Ikom Radio 107.7 FM.

Setelah pengumpulan data dilakukan dan data terkumpul, selanjutnya dilakukan proses reduksi data dengan melakukan pemilihan data yang bisa digunakan dan data diabaikan. Data yang terpilih selanjutnya dianalisis dengan menggunakan analisis data studi kasus yang dilakukan dengan melakukan kategori data. Setelah ada kategori data, dilanjutkan dengan mengatur data dengan empat cara, yaitu pencocokan pola, membangun penjelasan, menemukan logika model, dan melakukan analisis timeseries (Yin, 2008). Teknik tambahan dilakukan ketika menggunakan beberapa kasus, disebut sebagai sintesis untuk mencari pengulangan dalam kasus. Produk akhirnya adalah narasi yang menceritakan tentang kasus, yang memungkinkan pembaca sepenuhnya menjadi paham pada pada kasus yang terjadi (Prihatsanti et al., 2018).

\section{HASIL DAN PEMBAHASAN}

\section{MANAJEMEN IKOM RADIO 107.7 FM}

Sebagai bagian dari organisasi, radio dijalankan oleh sebuah struktur organisasi. Ikom Radio 107.7 FM sendiri merupakan radio kampus yang berisi sekumpulan mahasiswa yang tertarik pada dunia penyiaran terutama di bidang radio. Sebagian besar dari anggota Ikom Radio 107.7 FM berasal dari Program Studi Ilmu Komunikasi dan sebagian yang lain berasal dari Program Studi Hubungan Internasional dan Ilmu Pemerintahan. Masing-masing dari mereka, memiliki peranan yang sangat penting dalam menentukan kelanjutan dari Ikom Radio 107.7 FM, berikut merupakan sistem manajemen yang ada, Badan Pengurus Harian (BPH), Divisi Program, Divisi Produksi, Divisi Media Creative, Divisi Technical Support, dan Divisi Humas.

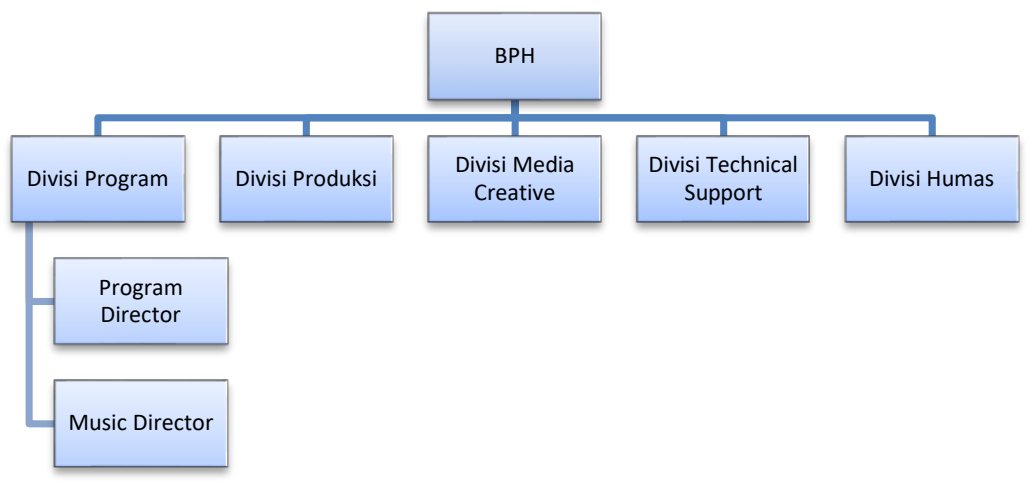

Gambar 1. Bagan Struktur Organisasi Ikom Radio 107.7 FM 
Dalam pelaksanaan programnya, Ikom Radio107.7 FM memiliki model manajemen yang membantu kelancaran pelaksanaan program. Dilihat secara fungsinya, ada empat fungsi manajemen yang terkenal, yaitu planning, organizing, actuating dan controlling atau sering disebut dengan PODC. Dimana fungsi planning dan organizing masuk ke kategori kegiatan mental, sedangkan actuating dan controlling masuk ke kategori kegiatan fisik (Sugiana et al., 2019).

Di Ikom Radio 107.7 FM, kegiatan perencanaan dilakukan dengan pengadaan rapat kerja sebelum mulainya periode kepengurusan. Rapat kerja dilakukan untuk membahas hal-hal yang akan dilakukan kedepannya, termasuk membahas mengenai strategi dan tujuan diadakannya suatu program. Untuk kegiatan pengorganisasian, Ikom Radio 107.7 FM membentuk struktur organisasi seperti yang sudah dijelaskan sebelumnya, hal ini dilakukan dalam rangka memudahkan pembagian tugas di tiap individu. Dalam pelaksanaan, terutama dalam hal pelaksanaan program siaran, Ikom Radio 107.7 FM melakukan siaran enam kali dalam satu minggu melalui proses tapping dan streaming di Website Ilmu Komunikasi UMY. Untuk kegiatan pengawasan, terutama dalam hal produksi program, yang melakukannya adalah $\mathrm{BPH}$ dengan mengadakan rapat evaluasi dua minggu sekali. Rapat evaluasi dilakukan untuk mengontrol program-program yang tengah berjalan.

Dalam mengelola sumber daya manusia saat siaran, Ikom Radio 107.7 FM memberikan kelonggaran bagi penyiar yang tidak bisa melakukan siaran di jadwalnya. Pertama, apabila tidak bisa melakukan siaran sesuai jadwal, bisa minta digantikan penyiar lain, dengan catatan dilakukan jauh-jauh hari dan melapor ke sekretaris Divisi Program. Kedua, apabila tidak menemukan pengganti siaran, maka akan di back-up oleh Divisi Program, dengan catatan sudah lapor dari jauh-jauh hari. Apabila tidak melapor saat berhalangan hadir dan sudah lebih dari dua kali, maka akan dilaporkan ke BPH dan akan mendapat konsekuensi sesuai yang ditetapkan BPH.

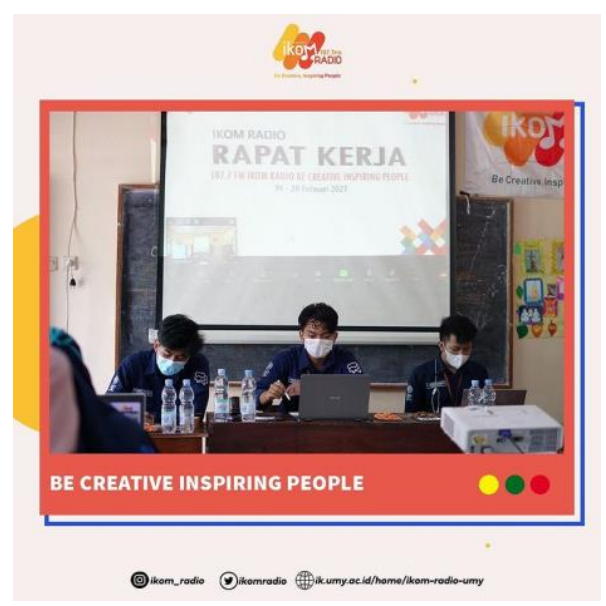

Gambar 2. Pelaksanaan Rapat Kerja Ikom Radio 107.7 FM

Dalam prinsipnya sebagai radio komunitas, Ikom Radio 107.7 FM melakukan siaran untuk menghibur dan memberi informasi kepada anggota komunitas yang merupakan khalayak terpilih. Untuk menganalisis khalayak, ada tiga elemen penting yang harus diperhatikan, yaitu segmentasi, targeting dan positioning. Segmentasi merupakan suatu strategi yang digunakan untuk memahami khalayak. Targetting bisa dikatakan sebagai target khalayak, yaitu persoalan bagaimana memilih, menyeleksi dan menjangkau khalayak. Positioning merupakan strategi untuk bisa masuk ke dalam benak khalayak (Kotler dalam Syarifudin, 2020)

Dalam aktualisasinya, segmentasi yang dilakukan oleh Ikom Radio 107.7 FM merupakan segmentasi berdasarkan demografis yang telah disesuaikan dengan visi Ikom Radio sebagai radio kampus, sehingga 
Ikom Radio menyasar mahasiswa UMY, tepatnya Mahasiswa Fakultas Ilmu Sosial dan Politik (FISIPOL) sebagai segmentasinya. Sehingga, yang menjadi target Ikom Radio adalah Mahasiswa FISIPOL UMY, Mahasiswa FISIPOL dipilih karena Ikom Radio merupakan bagian dari Badan Semi Otonom (BSO) yang masih berada dibawah naungan Korps Mahasiswa Ilmu Komunikasi (KOMAKOM) sehingga Ikom Radio 107.7 FM tidak bisa meluaskan target pasarnya. Sedangkan, untuk positioning, Ikom Radio melakukannya dengan melihat keseharian para mahasiswa, terutama melihat melalui interaksi mahasiswa di media sosial.

Dalam menghadapi segmentasi terpilih, Ikom Radio 107.7 FM menghadapi beberapa persoalan. Salah satunya adalah banyak mahasiswa dari Program Studi Hubungan Internasional dan Ilmu Pemerintahan yang belum mengetahui bahwa Ikom Radio 107.7 FM ada untuk seluruh Mahasiswa FISIPOL, baik dari segi kepengurusan maupun segmentasi pendengarnya. Karena itulah, saat ini Ikom Radio 107.7 FM berusaha untuk mengoptimalkan publikasi di kalangan mahasiswa Hubungan Internasional dan Ilmu Pemerintahan.

\section{MANAJEMEN PRODUKSI PROGRAM SIARAN IKOM RADIO 107.7 FM}

Analisis selanjutnya berkaitan dengan proses produksi program siaran di Ikom Radio 107.7 FM. Di awal pandemi Covid-19, Ikom Radio 107.7 sempat berhenti untuk beroperasi selama beberapa bulan. Hal ini terjadi karena keadaan yang mengharuskan semua pergerakan dibatasi belum pernah terjadi sebelumnya, sehingga perlu penyesuaian-penyesuaian baru agar Ikom Radio 107.7 FM bisa terus berjalan. Hingga akhirnya Ikom Radio 107.7 FM memulai siaran secara online dengan menggunakan Azuracast, control panel untuk radio streaming. Untuk tempat siarannya, Ikom Radio 107.7 FM menggunakan aplikasi dan website Ilmu Komunikasi UMY sebagai sarana mendengarkan siaran.

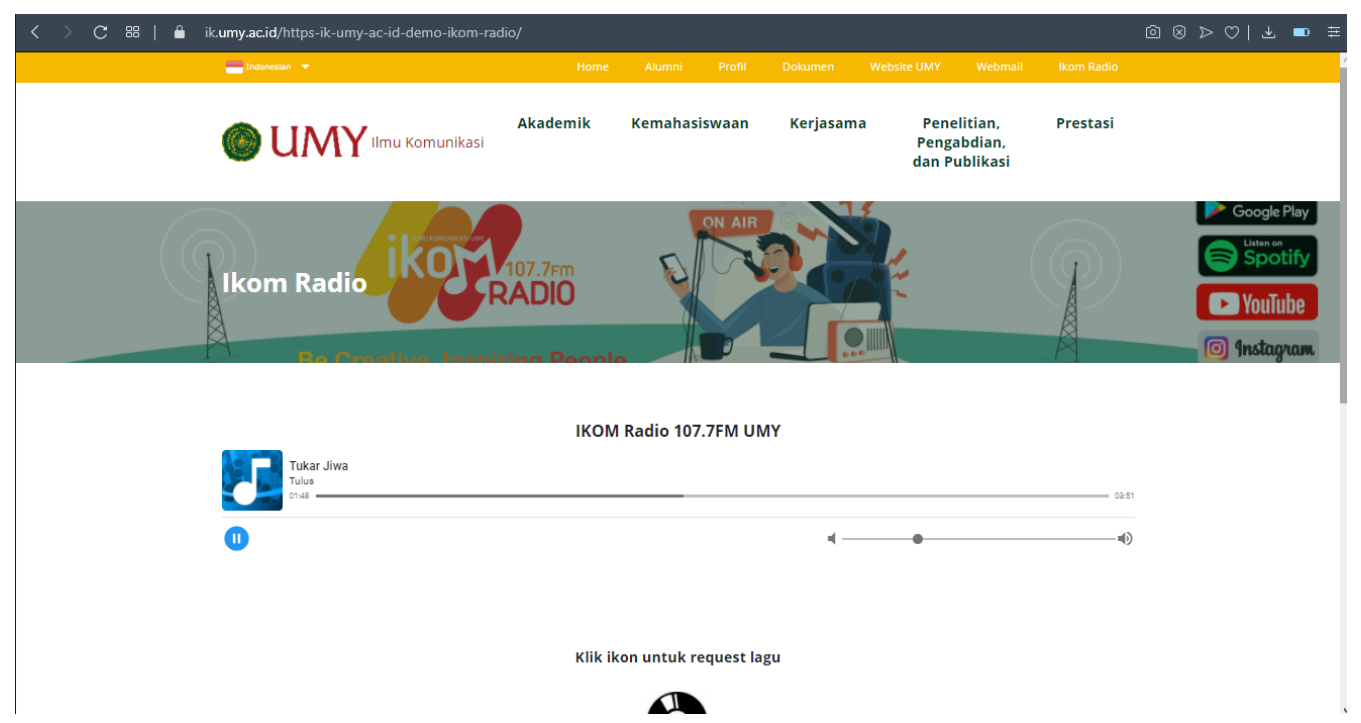

Gambar 3. Website Streaming Ikom Radio 107.7 FM

Departemen program dan departemen pemasaran merupakan departemen yang bertanggungjawab dalam hal merencanakan dan memilih program. Dua department ini bekerjasama dalam menyusun program yang baik dan memasarkan programnya, sehingga iklan bisa didapatkan oleh pengelola radio dengan demikian penghasilan finansial dapat diperoleh. Departemen pemasaran dapat memberikan masukan atas prospek peringkat acara (rating) bahkan lebih dari itu bisa mempengaruhi pada nilai saham perusahaan media tersebut apabila perusahaan media tersebut telah go public. Hubungan antara kedua bagian ini sangat vital untuk menjaga kesehatan keuangan media penyiaran (Morissan 2008:337 dalam Sugiana et al., 2019). 
Di Ikom Radio 107.7 FM, divisi yang bertanggungjawab atas produksi program adalah Divisi Program dan Divisi Produksi. Divisi Program melakukan brainstorming dengan melihat program-program siaran yang sudah ada sebelumnya, melakukan research dengan mendengarkan radio-radio komersiil, melihat isuisu yang sedang banyak diperbincangkan serta melihat keseharian mahasiswa. Setelah itu, Divisi Program akan melakukan diskusi untuk menentukan program yang akan dilanjutkan juga program baru apa yang akan dimunculkan. Divisi Produksi di Ikom Radio 107.7 FM lebih berfokus pada pembuatan Radio Expose (RE), Smash serta Cue.

Saat ini setiap stasiun radio harus bersaing dalam memperebutkan perhatian pendengar. Radio tidak bisa lagi 'memerintahkan' audiens. Radio harus mampu merayu audiens. Hal ini merupakan tantangan terbesar dari semuanya. Kondisi saat ini, tidak memungkinkan untuk sekedar menyiarkan berita, seorang jurnalis radio harus memastikan bahwa berita didengarkan dan dipahami. Untuk menginformasikan, seorang penyiar harus tertarik mengenai berita yang disampaikan (Chantler \& Stewart, 2009). Morissan dalam Sugiana mengatakan bahwa faktor penting dalam mendukung kesehatan keuangan perusahaan media adalah program acara yang mendapat apresiasi audience, program yang mampu menyedot perhatian khalayaknya sehingga mampu mendatangkan para pengiklan untuk mengiklankan produknya di program acara stasiun tersebut.

Ikom Radio 107.7 FM berusaha merebut perhatian pendengar dengan melakukan pendekatanpendekatan di kehidupan sehari-hari. Selain melakukan pendekatan dengan lebih sering berinteraksi melalui media sosial, Ikom Radio 107.7 FM juga melihat bahwa mahasiswa saat ini banyak yang suka mengeluh akan tugas kuliah, kehidupan kuliah dsb. Atas dasar tersebut, Ikom Radio menghadirkan suatu program acara yang dinamakan "Sambat", program ini berisi curahan hati dari para pendengar mengenai apa yang sedang dialaminya. Selain itu, realitas lain yang diambil untuk dijadikan program adalah fenomena jatuh cinta yang sering membuat anak muda bahagia meski hanya menceritakannya. Dari realitas tersebut, muncullah suatu program yang bernama "Bucin Time".

\section{PROSES SIARAN IKOM RADIO 107.7 FM}

Dikarenakan keadaan yang belum memungkinkan untuk melakukan siaran secara on air, hingga saat ini Ikom Radio 107.7 FM masih melakukan siaran dengan proses tapping secara online. Proses tapping dilakukan oleh masing-masing penyiar melalui aplikasi Zoom yang kemudian diubah ke MP3 untuk kemudian diserahkan pada Divisi Technical Support.

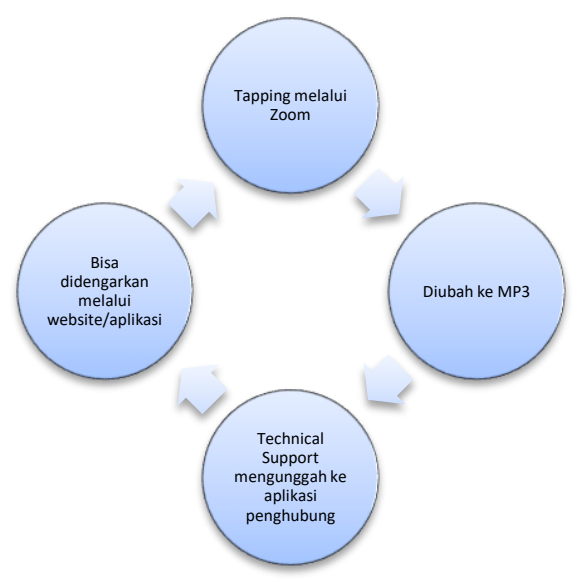

Gambar 4. Proses Siaran di Ikom Radio 107.7 FM 


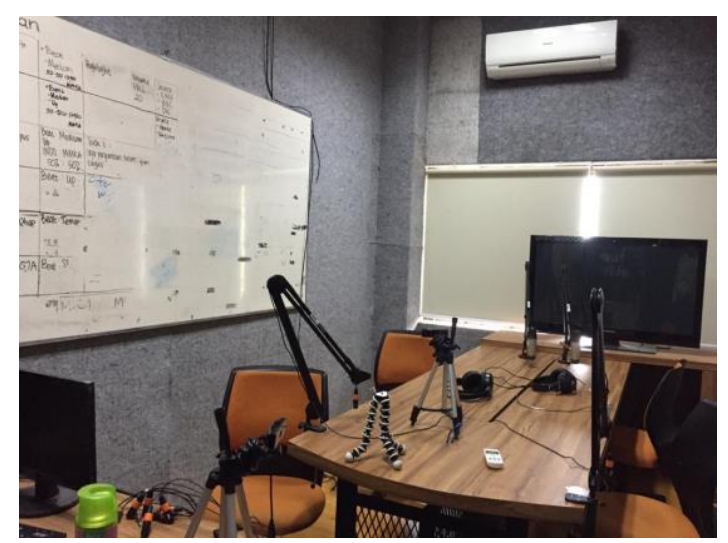

Gambar 5. Studio Ikom Radio 107.7 FM

Divisi Technical Support bertugas untuk mengunggah hasil tapping menggunakan aplikasi penghubung, hingga akhirnya bisa didengar melalui website ataupun aplikasi. Untuk beberapa penyiar yang ada di Jogja, diperbolehkan untuk menggunakan studio Ikom Radio 107.7 FM dalam melaksanakan tapping.

\section{KESIMPULAN}

Adanya Pandemi Covid-19 membuat banyak tatanan sosial masyarakat berubah. Penyesuaian demi penyesuaian dilakukan agar dapat bertahan di tengah pandemi. Tuntutan perubahan membuat hal-hal yang tidak pernah dibayangkan mulai bermunculan. Selama pandemi Covid-19, Ikom Radio 107.7 FM menjalankan proses siaran secara online. Termasuk dalam menentukan program yang akan disajikan pada para pendengar. Dalam penentuannya, Divisi Program akan melakukan brainstorming dengan melihat program-program siaran yang sudah ada sebelumnya, melakukan research dengan mendengarkan radioradio komersiil, melihat isu-isu yang sedang banyak diperbincangkan serta melihat keseharian mahasiswa. Hasil dari brainstorming tersebut memunculkan beberapa program baru yang relate dengan kehidupan mahasiswa saat ini. Dalam mengelola sumber daya manusia saat siaran, Ikom Radio 107.7 FM memberikan kelonggaran bagi penyiar yang tidak bisa melakukan siaran di jadwalnya.

\section{PERSANTUNAN}

Terima kasih kepada Dr. Fajar Junaedi yang telah membimbing proses riset dalam mata kuliah Manajemen Media Penyiaran di Program Studi Ilmu Komunikasi UMY, selama satu semester genap tahun akademik 2020/2021 yang menghasilkan luaran berupa artikel ini.

\section{REFERENSI}

Gama, H. S. K. (2018). Peningkatan Kreativitas Mahasiswa Melalui Manajemen Kepenyiaran Radio Kampus. Prosiding Seminar Nasional Tahun 2018 Publikasi Hasil Penelitian Dan Pengabdian Kepada Masyarakat, 93.

Bharata, B. S., Jati, R. P., Shean, T. K., Poernamasari, N., Maryam, S., Aina, I. F., Abdul, N., Nagib, M., Prima, D., Sanjaya, L. D., Monica, R., Chinta, A., Ibrahim, I. S., Kamarulbaid, A. M., Anita, W., Abas, W., Omar, S. Z., Bidin, R., Yusmindarsih, A., ... Kristanti, S. (2018). New Media in Disruption Era (F. Junaedi \& A. Wibowo (eds.); 1st ed.). Asosiasi Pendidikan Tinggi Ilmu Komunikasi (ASPIKOM) Indonesia In cooperation with ASPIKOM Region South Sumatera And Buku Litera Yogyakarta.

Chantler, P., \& Stewart, P. (2009). Essential Radio Journalism. A\&C Black Publishers Limited.

Given, L. M. (2008). The SAGE Encyclopedia of QUALITATIVE RESEARCH METHODS. VOLUME $1 \mathbb{E}$ 
2 (p. 886). Singapore: A SAGE Reference Publication.

Husna, N., Siswantini \& Nathania, L., Sasongko, Y. P. D., Ichsan, M. N., Kencana, W. H., Pasaribu, R., Handayani, F., Evelina, L. W., Dinansyah, F., Dei, R. D. L. P. D., Faramita, A., Hereyah, Y., Putri, V. K. A., Husna, F., Hidajat, K., Basarah, F. F., Yulita, H., Dhamayanti, M., Prawira, I., ... Situmeang, I. R. (2020). Adaptasi Disiplin Ilmu Komunikasi di Masa Normal Baru (L. Yudhi (ed.); 1st ed.). CV. Putra Media Nusantara (PMN), Surabaya.

Nasution, N. (2018). Strategi Manajemen Penyiaran Radio Swasta Kiss Fm dalam Menghadapi Persaingan Informasi Digital. Interaksi, 2(2), 173.

Prihatsanti, U., Suryanto, S., \& Hendriani, W. (2018). Menggunakan Studi Kasus sebagai Metode Ilmiah dalam Psikologi. Buletin Psikologi, 26(2), 126. https://doi.org/10.22146/buletinpsikologi.38895

Sari, P. A., Sari, Y., \& Rizky, D. (2011). Dibalik Sandiwara Program Geronimo FM. Jurnal Komunikator, 67.

Sugiana, D., Setiaman, A., Sari, D. K., Wibowo, N. A., Herwandito, S., Sjuchro, D. W., Yusanto, Y., Ramadhani, E., Nuraini, I., Kodrat, D., Samudro, A., Gemiharto, I., Gobang, J. K., Karimah, K. El, Wahyudin, U., Tarifu, L., Nurfikria, I., Lusianai, W. O., Jabar, A. S., ... Hariyanti, P. (2019). Komunikasi dalam Media Digital (F. Junaedi \& F. G. Sukmono (eds.)). Buku Litera Yogyakarta.

Syarifudin, T. (2020). Model Manajemen Media Komunitas Berbasis Fans Sepak Bola Pasoepati.Net dalam Perspektif Structure Conduct Perform (SCP). Jurnal Audiens, 1(2). https://doi.org/10.18196/ja.12017

Yin, R. K., \& Djauzi Mudzakir, M. (2008). Studi kasus : desain $\mathcal{E}$ metode / Robert K. Yin; penerjemah, M. Djauzi Mudzakir. RajaGrafindo Perkasa. 